\title{
Humus and physicochemical properties of Forest-Steppe chernozems at minimization of treatments and biologization of the fertilizer system
}

\author{
Balayev A. ${ }^{1}$, Tonkha $0 .{ }^{2}$, Pikovska $0 .{ }^{3}$, Havry-liuk M. ${ }^{4}$, Shemetun K. ${ }^{5}$ \\ ${ }^{1-5}$ National university of life and environmental sciences of Ukraine \\ 15 Heroiv Oborony Str., Kyiv, 03041, Ukraine

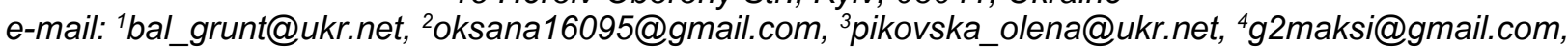 \\ ${ }^{5}$ katerinamakarchuk@ukr.net \\ ORCID: 20000-0002-0677-5494, 30000-0002-5052-9223, 40000-0001-5510-1384, 50000-0001-8293-
} 6213

The purpose. To determine the ways of restoration of the fertility of typical and podzolic chernozems at longterm use with minimal tillage and biologization of crop fertilizer systems in short crop rotations of the RightBank Forest-Steppe. Methods. Field, laboratory, comparative-calculation, and statistical. Soil samples according to the variants of stationary experiments were taken from depths of $0-15,15-30,30-45$, and 45 $-60 \mathrm{~cm}$. The content of total humus, hydrolytic acidity, and the amount of absorbed bases were determined in them. Results. The research was carried out in 2 long stationary experiments to study the impact of tillage and fertilizer systems on the content and reserves of humus and indicators of physicochemical properties of the soil. The use of straw and green manure on podzolic chernozem instead of manure helped to increase the content and stocks of humus. The combination of manure, straw, green manure, and half of the dose of mineral fertilizers with the use in the crop rotation of tillage with periodic plowing under sugar beets formed the highest reserves of humus in the $0-45 \mathrm{~cm}$ soil layer. For typical chernozem, the best results of humus state were fixed at shallow tillage and use of straw, green manure, and mineral fertilizers. Conclusions. Minimization of tillage and biologization of the fertilizer system in short- crop rotations of the Right-Bank Forest-Steppe contributed to the increase of humus reserves, improvement of physicochemical properties of typical and podzolic chernozems, which led to the restoration of their fertility. The highest fertility of typical chernozem was restored by shallow tillage with different depths using a straw, greens, and mineral fertilizers. The highest fertility of the podzolic chernozem was restored by shallow tillage with periodic plowing and application of manure or straw and straw and green manure and complete mineral fertilizer.

Key words: podzolic and typical chernozem, humus content, humus reserves, plowing, Shallow tillage,

Right-Bank Forest-Steppe of Ukraine, short crop rotations.

DOI: https://doi.org/10.31073/agrovisnyk202011-03

The restoration of soil fertility is a generally accepted problem in modern agriculture, which could not be solved either during the periods of chemurgy and the intensification of agriculture or during the years of independent Ukraine [1, 2]. The content of soil organic matter, as integrated indicator of its fertility, has been steadily declining since the 60 s and 70 s of the last century. First, it is observed in chernozems, which provide the bulk of gross crop production [3, 4]. The main reasons for the decrease in the fertility of chernozem are insufficient application of organic and mineral fertilizers, and an unbalanced composition of the last one. Intensive soil cultivation and saturation of crop rotations with highly productive crops leads to an insufficient balance of humus and fertilizer elements in the soils. In modern conditions, the main ways to reduce the mechanical and chemical loading on chernozems and reach a deficit-free balance of humus, as the basis for restoring their fertility, can be minimization of soil cultivation and biologization of the fertilizer system, involves the usage of straw, by-products, green manure and mineral fertilizers in moderate rates to return the soil elements, which were taken out with the harvest [5-9]. V Volkohon and others [10] conclude that the systemic application of mineral fertilizers without providing the soil with fresh organic matter leads to an imbalance of mineralization $\leftrightarrow$ synthesis. Under these conditions, the mineralization of organic matter dominates.

In Ukraine, despite the significant number of studies on topic the impact of different tillage systems in combination with organo-mineral fertilizers, the issue of comprehensive assessment of their impact on chernozem fertility is not fully clarified [11,12]. This assessment should be based not only on crop yields, which is commonly practiced in the works, but also on the main properties of chernozems, at least in the upper half-meter soil layer. Fertility is the ability of the soil to provide the plant with water, and nutrients. It is determined by the entire composition and properties of the soil in the root layer, therefore its assessment should be approached more systematically and accurately [13, 14].

The purpose of research. To establish ways to restore the fertility of typical and podzolic chernozems with long-term use of minimizing tillage and biologization of crop fertilization systems in short-rotation crop rotations of the Right-Bank Forest-Steppe.

Materials and methods of research. The research was carried out in the period 2009-2015 in shortrotation crop rotations of stationary experiments in 1991 based on podzolic medium loam chernozem of 
Khmelnytsky research station with crop rotation as: peas - winter wheat - sugar beets - spring barley - silage corn, as well as on typical medium loam chernozem of stationary experiment of Professor M.K. Shykula Department of Soil Science and Soil Conservation NUBip of Ukraine (Kyiv region) in 1998 with the rotation of soybean - winter wheat - grain corn - spring barley.

Podzolic medium loam chernozem on loess has the following physicochemical and agrochemical indicators in the layer of $0-30 \mathrm{~cm}$ : the content of humus according to Tyurin $-3.64 \%, \mathrm{pH}$. $-5.4, \mathrm{Hr}-2.98$ $\mathrm{mEq} / 100 \mathrm{~g}$ of soil, $\mathrm{S}-25.5 \mathrm{mEq} / 100 \mathrm{~g}$ of soil, high nitrogen supply of easily hydrolyzed compounds according to Tyurin-Kononova and mobile phosphorus and average potassium according to Chirikov, and typical medium loam chernozem on loess: humus content according to Tyurin $-3.57 \%, \mathrm{pH} .-6.3, \mathrm{Hr}-0.91$ $\mathrm{mEq} / 100 \mathrm{~g}$ of soil, $\mathrm{S}-26.0 \mathrm{mEq} / 100 \mathrm{~g}$ of soil and average supply of nitrogen, phosphorus and potassium.

The following tillage systems at the Khmelnytsky research station were studied in stationary experiments: a five-field crop rotation, systematic plowing and non-plow tillage were compared with regular plowing under sugar beets; on typical chernozem of stationary experiment of the Department of Soil Science and Soil Conservation - systematic plowing tillage and two non-plow tillage - different depth for different crops by $10-25 \mathrm{~cm}$ and shallow non-plow tillage for all crops by $10-12 \mathrm{~cm}$. Fertilizer rates per 1 ha of crop rotation area are presented in the charts.

Soil samples were taken from a depth of 0-15, 15-30, 30-45 and 45-60 cm, accordingly [15], followed by determination of humus content in compliance with Public Standard DSTU 4289: 2004 [16], the amount of absorbed bases [17], hydrolytic acidity [18].

The results of research. Restoration of chernozem fertility should be based on ensuring a deficit-free balance of humus and nutrients, in other words stabilization of their content and reserves [19, p.72]. In studies [20] found that the use of minimum tillage led to an increase organic matter content by $0.8-22.1 \%$ in the soil. As a result of previous studies [11,21] it was found that the systematic application of organomineral fertilizer helps to restore the humus content and improves the physicochemical properties of soils.

Chart 1 presents the changes in the content and reserves of humus in podzolic chernozem under the influence of tillage and fertilizer systems. It should be mentioned that all possible measures to restore soil fertility can be divided into two groups - "material" and "technological". Fertilizer application belongs to the first group of measures and they have a greater impact on changes in the content and reserves of humus, and the increase in the amount of fresh organic matter is accompanied by a corresponding increase of humus in the content and reserves. Co-application of straw and green manure was effective for humus formation and restoration of fertility of podzolic chernozem and demonstrates non-inferiority to the efficiency of only manure application. Thus, the biologization of the fertilization system contributed to the increase of organic matter reserves of podzolic chernozem and the reproduction of soil fertility. The largest reserves of humus were observed with the joint application of manure and straw.

Reducing the intensity of cultivation in short-rotation crop rotation by a combination of non-plow tillage and plowing tillage contributed to the preservation and accumulation of humus in podzolic chernozem compared to systematic plowing, especially with the sufficient application of organic fertilizers. In the variants without fertilizers and the aplication of only mineral fertilizers led to redistribution of humus reserves depending on the tillage system. During the non-plow tillage, the humus content increased and the humus reserves of the upper layer increased. In addition, they were distributed more equally between the layers during plowing. The largest reserves of humus were on the non-plow cultivation with periodic plowing and joint application of manure and straw.

Thus, the application of straw, green manure and complete mineral fertilizers in non-plow tillage, the content of humus and its reserves in the layers of $0-15,15-30$ and $30-45 \mathrm{~cm}$, respectively, was $4.00 \pm 0.03$; $3.94 \pm 0.03 ; 2.99 \pm 0.05$; and $73.2 ; 72.0 ; 55.9 \mathrm{t} / \mathrm{ha}$, at the same time for plowing the values were $3.80 \pm 0.03$; $3.68 \pm 0.04 ; 2.63 \pm 0.04$ and $70.7 ; 69.6$ and 51.3 t/ha (Table 1$)$.

\section{The content and reserves of humus in podzolic chernozem under different systems of tillage and fertilization}

\begin{tabular}{|c|c|c|c|c|c|}
\hline \multirow{2}{*}{$\begin{array}{c}\text { Fertilizer option } \\
\text { per/ha of crop } \\
\text { rotation }\end{array}$} & \multirow{2}{*}{$\begin{array}{c}\text { Soil layers, } \\
\mathrm{cm}\end{array}$} & \multicolumn{2}{|c|}{ Humus content,\% } & \multicolumn{2}{c|}{$\begin{array}{c}\text { Reserves of humus, } \\
\mathrm{t} / \text { ha }\end{array}$} \\
\cline { 2 - 6 } & & tillage & disk plowing & tillage & disk plowing \\
\hline \multirow{2}{*}{$\begin{array}{c}\text { Without fertilizers } \\
\text { (control) }\end{array}$} & $0-15$ & $3,51 \pm 0,03$ & $3,66 \pm 0,03$ & 65,3 & 67,0 \\
\cline { 2 - 6 } & $15-30$ & $3,45 \pm 0,05$ & $3,48 \pm 0,03$ & 65,2 & 66,3 \\
\cline { 2 - 6 } & $30-45$ & $2,22 \pm 0,04$ & $2,21 \pm 0,04$ & 43,3 & 41,8 \\
\hline \multirow{3}{*}{$\mathrm{N}_{110} \mathrm{P}_{61} \mathrm{~K}_{118}$} & $0-15$ & $3,52 \pm 0,03$ & $3,70 \pm 0,03$ & 65,5 & 67,7 \\
\cline { 2 - 6 } & $15-30$ & $3,44 \pm 0,03$ & $3,45 \pm 0,03$ & 65,0 & 65,7 \\
\cline { 2 - 6 } & $30-45$ & $2,38 \pm 0,05$ & $2,33 \pm 0,04$ & 46,4 & 44,0 \\
\hline \multirow{2}{*}{$\mathrm{N}_{110} \mathrm{P}_{61} \mathrm{~K}_{118}+$} \\
straw+N $\mathrm{N}_{10} / \mathrm{t}$
\end{tabular}




\begin{tabular}{|c|c|c|c|c|c|}
\hline \multirow{3}{*}{$\begin{array}{c}\mathrm{N}_{110} \mathrm{P}_{61} \mathrm{~K}_{118}+ \\
\text { straw }+\mathrm{N}_{10} / \mathrm{t}+ \\
\text { green manure }\end{array}$} & $0-15$ & $3,80 \pm 0,03$ & $4,00 \pm 0,03$ & 70,7 & 73,2 \\
\hline & $15-30$ & $3,68 \pm 0,04$ & $3,78 \pm 0,04$ & 69,6 & 72,0 \\
\hline & $30-45$ & $2,63 \pm 0,04$ & $2,96 \pm 0,04$ & 51,3 & 55,9 \\
\hline \multirow{3}{*}{$\begin{array}{c}\mathrm{N}_{55} \mathrm{P}_{30} \mathrm{~K}_{59}+ \\
\text { manure } 8 \mathrm{t} / \mathrm{ha}\end{array}$} & $0-15$ & $3,94 \pm 0,03$ & $4,01 \pm 0,03$ & 72,3 & 73,3 \\
\hline & $15-30$ & $3,79 \pm 0,03$ & $3,94 \pm 0,03$ & 72,6 & 75,1 \\
\hline & $30-45$ & $2,68 \pm 0,04$ & $2,99 \pm 0,05$ & 52,3 & 56,4 \\
\hline \multirow{3}{*}{$\begin{array}{c}\mathrm{N}_{55} \mathrm{P}_{30} \mathrm{~K}_{59}+ \\
\text { manure } 8 \mathrm{t} / \mathrm{ha}+ \\
\text { straw }+\mathrm{N}_{10} / \mathrm{T}\end{array}$} & $0-15$ & $3,90 \pm 0,03$ & $4,16 \pm 0,03$ & 71,6 & 76,1 \\
\hline & $15-30$ & $3,82 \pm 0,05$ & $3,99 \pm 0,04$ & 72,3 & 76,0 \\
\hline & $30-45$ & $2,72 \pm 0,04$ & $3,02 \pm 0,05$ & 53,0 & 57,0 \\
\hline \multirow{3}{*}{$\begin{array}{c}\mathrm{N}_{55} \mathrm{P}_{30} \mathrm{~K}_{59}+ \\
\text { manure } 8 \mathrm{t} / \mathrm{ha}+ \\
\text { straw }+\mathrm{N}_{10} / \mathrm{t}+ \\
\text { green manure }\end{array}$} & $0-15$ & $3,79 \pm 0,03$ & $4,05 \pm 0,03$ & 70,5 & 74,1 \\
\hline & $15-30$ & $3,68 \pm 0,04$ & $3,86 \pm 0,04$ & 69,6 & 73,5 \\
\hline & $30-45$ & $2,65 \pm 0,04$ & $2,82 \pm 0,04$ & 51,7 & 53,3 \\
\hline
\end{tabular}

The same regularities were observed with the use of different tillage and fertilization systems on typical chernozem (Table 2). The application of organic fertilizers helped to increase the content and reserves of humus, and their quantity depended on the amount of fresh organic matter entering the soil. The content and reserves of humus without fertilizers were the smallest and in the layer of $0-40 \mathrm{~cm}$ are almost the same in all cultivation options, although there was already a noticeable redistribution of reserves depending on the tillage system and the degree of its minimization. The differentiation of the cultivated soil layer intensified with the application of fertilizers and became especially noticeable in the variant of shallow non-plow tillage, where reserves were restored mainly in the upper layers. The combination of a relatively low rate of straw with green manure contributed to increased humus accumulation. Furthermore, fertilization had also higher content and reserves of humus in this case. Non-plow tillage had an advantage over plowing in restoring the fertility of typical chernozem especially on different depth, where the highest reserves of humus were observed on fertilized backgrounds. The content and reserves of humus on shallow non-plow tillage decreased dramatically down the soil layers in the case of the application of straw, green manure and mineral fertilizers was $4.25 \pm$ $0.03 ; 3.98 \pm 0.04 ; 3.54 \pm 0.04 \%$ and $51.8 ; 50.1$ and $44.6 \mathrm{t} / \mathrm{ha}$.

\section{The content and reserves of humus in typical chernozem in different systems of tillage and fertilization}

\begin{tabular}{|c|c|c|c|c|c|c|c|}
\hline \multirow[b]{2}{*}{$\begin{array}{c}\text { Fertilizer } \\
\text { option } \\
\text { per/ha of } \\
\text { crop rotation }\end{array}$} & \multirow[b]{2}{*}{$\begin{array}{l}\text { Soil } \\
\text { layers, } \\
\text { cm }\end{array}$} & \multicolumn{3}{|c|}{ Humus content, \% } & \multicolumn{3}{|c|}{$\begin{array}{c}\text { Reserves of humus, } \\
\text { t/ha }\end{array}$} \\
\hline & & $\begin{array}{c}\text { No } \\
\text { fertilizers }\end{array}$ & $\begin{array}{c}\text { Straw } 1,2 \\
\text { t/ha+ } \\
\mathrm{N}_{12}+ \\
\mathrm{N}_{74} \mathrm{P}_{68} \mathrm{~K}_{68}\end{array}$ & $\begin{array}{c}\text { Straw } 1,2 \\
\text { t/ha+ } \\
\mathrm{N}_{12}+\text { green } \\
\text { manure+ } \\
\mathrm{N}_{74} \mathrm{P}_{68} \mathrm{~K}_{68}\end{array}$ & $\begin{array}{c}\text { No } \\
\text { fertilizers }\end{array}$ & $\begin{array}{c}\text { Straw } 1,2 \\
\text { t/ha+ } \\
\mathrm{N}_{12}+ \\
\mathrm{N}_{74} \mathrm{P}_{68} \mathrm{~K}_{68}\end{array}$ & $\begin{array}{c}\text { Straw } 1,2 \\
\text { t/ha }+ \\
\mathrm{N}_{12}+\text { greenm } \\
\text { anure }+ \\
\mathrm{N}_{74} \mathrm{P}_{68} \mathrm{~K}_{68}\end{array}$ \\
\hline \multirow{4}{*}{ Plowing } & $0-15$ & $3,50 \pm 0,03$ & $3,96 \pm 0,03$ & $4,08 \pm 0,03$ & 42,7 & 48,3 & 49,8 \\
\hline & $15-30$ & $3,48 \pm 0,03$ & $3,94 \pm 0,03$ & $4,06 \pm 0,03$ & 42,5 & 48,0 & 49,5 \\
\hline & $30-45$ & $3,14 \pm 0,04$ & $3,58 \pm 0,04$ & $3,68 \pm 0,04$ & 39,9 & 45,5 & 46,7 \\
\hline & $45-60$ & $2,84 \pm 0,04$ & $3,04 \pm 0,04$ & $3,02 \pm 0,05$ & 34,6 & 36,7 & 36,8 \\
\hline \multirow{4}{*}{$\begin{array}{l}\text { Non-plow tillage } \\
\text { on different- } \\
\text { depth }\end{array}$} & $0-15$ & $3,58 \pm 0,03$ & $4,16 \pm 0,03$ & $4,22 \pm 0,03$ & 44,0 & 51,2 & 51,9 \\
\hline & $15-30$ & $3,44 \pm 0,05$ & $3,98 \pm 0,03$ & $4,10 \pm 0,03$ & 42,6 & 4,4 & 50,8 \\
\hline & $30-45$ & $3,12 \pm 0,03$ & $3,54 \pm 0,04$ & $3,64 \pm 0,04$ & 38,7 & 43,9 & 45,1 \\
\hline & $45-60$ & $2,84 \pm 0,04$ & $3,06 \pm 0,04$ & $3,30 \pm 0,04$ & 34,4 & 37,0 & 39,9 \\
\hline \multirow{4}{*}{$\begin{array}{c}\text { Shallow } \\
\text { non-plow tillage }\end{array}$} & $0-15$ & $3,66 \pm 0,03$ & $4,12 \pm 0,03$ & $4,25 \pm 0,03$ & 44,7 & 50,3 & 51,8 \\
\hline & $15-30$ & $3,40 \pm 0,03$ & $3,91 \pm 0,03$ & $3,98 \pm 0,04$ & 42,8 & 49,3 & 50,1 \\
\hline & $30-45$ & $3,12 \pm 0,04$ & $3,37 \pm 0,04$ & $3,54 \pm 0,04$ & 39,3 & 42,5 & 44,6 \\
\hline & $45-60$ & $2,74 \pm 0,04$ & $2,94 \pm 0,04$ & $2,94 \pm 0,05$ & 33,2 & 35,6 & 35,6 \\
\hline
\end{tabular}


Soil fertility is determined by all its composition and properties and it is revealed through the provision plants with water and nutrients. The great importance has physicochemical properties, which characterize the reaction of the soil environment, the number and composition of metabolic bases, the saturation of the soilabsorbing complex etc. Table 3 shows the changes in hydrolytic acidity and the amount of cations exchange of podzolic chernozem influnced by tillage and fertilization systems.

3. Hydrolytic acidity and the numbers of exchange bases of podzolic chernozem under different systems of tillage and fertilization, $\mathrm{mEq} / 100 \mathrm{~g}$ of soil

\begin{tabular}{|c|c|c|c|c|c|}
\hline \multirow{2}{*}{$\begin{array}{c}\text { Fertilizer } \\
\text { option } \\
\text { per/ha of } \\
\text { crop rotation }\end{array}$} & \multirow[b]{2}{*}{$\begin{array}{l}\text { Soil layers, } \\
\text { cm }\end{array}$} & \multicolumn{2}{|c|}{ Plowing } & \multicolumn{2}{|c|}{ Non-plow tillage } \\
\hline & & $\mathrm{Hr}$ & S & $\mathrm{Hr}$ & S \\
\hline \multirow{2}{*}{$\begin{array}{l}\text { No fertilizer } \\
\text { (control) }\end{array}$} & $0-30$ & 3,20 & 25,8 & 2,82 & 26,5 \\
\hline & $30-45$ & 1,70 & 25,2 & 1,60 & 25,0 \\
\hline \multirow{2}{*}{$\mathrm{N}_{110} \mathrm{P}_{61} \mathrm{~K}_{118}$} & $0-30$ & 4,28 & 25,4 & 3,46 & 26,2 \\
\hline & $30-45$ & 2,70 & 24,8 & 2,56 & 24,8 \\
\hline \multirow{2}{*}{$\begin{array}{c}\mathrm{N}_{110} \mathrm{P}_{61} \mathrm{~K}_{118}+ \\
\text { straw+N }+\mathrm{N}_{10} / \mathrm{t}\end{array}$} & $0-30$ & 4,38 & 25,6 & 3,12 & 26,5 \\
\hline & $30-45$ & 2,16 & 24,9 & 1,94 & 25,4 \\
\hline \multirow{2}{*}{$\begin{array}{c}\mathrm{N}_{110} \mathrm{P}_{61} \mathrm{~K}_{118}+ \\
\text { straw+N } \\
\text { green manure }\end{array}$} & $0-30$ & 4,24 & 25,8 & 3,10 & 28,0 \\
\hline & $30-45$ & 2,05 & 25,2 & 1,90 & 26,8 \\
\hline \multirow{2}{*}{$\begin{array}{c}\mathrm{N}_{55} \mathrm{P}_{30} \mathrm{~K}_{59}+ \\
\text { manure } 8 \mathrm{t} / \mathrm{ha}\end{array}$} & $0-30$ & 1,90 & 28,1 & 1,70 & 28,4 \\
\hline & $30-45$ & 1,12 & 26,4 & 1,10 & 26,8 \\
\hline \multirow{2}{*}{$\begin{array}{c}\mathrm{N}_{55} \mathrm{P}_{30} \mathrm{~K}_{59}+ \\
\text { manure } 8 \mathrm{t} / \mathrm{ha}+ \\
\text { straw }+\mathrm{N}_{10} / \mathrm{T}\end{array}$} & $0-30$ & 2,26 & 28,4 & 2,20 & 29,0 \\
\hline & $30-45$ & 1,08 & 27,3 & 1,17 & 27,2 \\
\hline \multirow{2}{*}{$\begin{array}{c}\mathrm{N}_{55} \mathrm{P}_{30} \mathrm{~K}_{59}+ \\
\text { manure } 8 \mathrm{t} / \mathrm{ha}+ \\
\text { straw }+\mathrm{N}_{10} / \mathrm{t}+ \\
\text { green manure }\end{array}$} & $0-30$ & 2,24 & 28,0 & 2,12 & 28,5 \\
\hline & $30-45$ & 1,52 & 28,0 & 1,40 & 27,6 \\
\hline
\end{tabular}

The chart shows that the indicators of physicochemical properties of podzolic chernozem were influenced by systems of both fertilization and tillage. Hydrolytic acidity increased in the upper layer with the application of straw and mineral fertilizers increased to $4.38 \mathrm{mEq} / 100 \mathrm{~g}$ of soil in the variant for plowing. Manure application contributed to the acidity reduction to favorable values for growth and development of crops: for plowing with joint application of manure and mineral fertilizers, hydrolytic acidity was $1.9 \mathrm{mEq} / 100$ $\mathrm{g}$ per plowing and 1.7 - for non-plow tillage cultivation in $0-30 \mathrm{~cm}$ layer. Slightly higher values were observed in case of joint application of straw and manure: 2.26 and $2.20 \mathrm{mEq} / 100 \mathrm{~g}$, accordingly, for plowing and non-plow tillage. Similar values of hydrolytic acidity were also observed in case of joint application of manure, straw and green manure: 2.26 and $2.12 \mathrm{mEq} / 100$.

The amount of exchange bases correlated with the humus content in podzoliz chernozem in different variants. In the variants without fertilizers and with the application of only mineral fertilizers - it was low, with the application of straw and green manure - it did not increase significantly too, but it increased significantly with the application of manure. First of all, this increase can be explained by a decrease in hydrolytic acidity and an increase of the humus content in the upper layers. Non-plow tillage with periodic plowing reduced the hydrolytic acidity of the layers by pulling up carbonates, which was mentioned in other studies [8]. Reducing the acidity and increasing the humus content during such cultivation contributed to the stability of cations and increased the amount of exchange bases. The best indicators were the variants with the combined application of manure, straw and green manure under condition of non-plow tillage. 


\section{Hydrolytic acidity and the sum of exchange bases of typical chernozem for different systems of}

soil tillage and fertilization, meq/100 $\mathrm{g}$ of soil

\begin{tabular}{|c|c|c|c|c|c|c|c|}
\hline \multirow{2}{*}{$\begin{array}{c}\text { Fertilizer } \\
\text { option } \\
\text { per / ha of } \\
\text { crop rotation }\end{array}$} & \multirow{2}{*}{$\begin{array}{l}\text { Soil } \\
\text { layers, } \\
\mathrm{cm}\end{array}$} & \multicolumn{2}{|c|}{ No fertilizers } & \multicolumn{2}{|c|}{$\begin{array}{c}\text { Straw } 1,2 \mathrm{t} / \mathrm{ha}+\mathrm{N}_{12}+ \\
\mathrm{N}_{74} \mathrm{P}_{68} \mathrm{~K}_{68}\end{array}$} & \multicolumn{2}{|c|}{$\begin{array}{c}\text { Straw } 1,2 \mathrm{t} / \text { ha }+ \\
\mathrm{N}_{12}+\text { green manure }+ \\
\mathrm{N}_{74} \mathrm{P}_{68} \mathrm{~K}_{68}\end{array}$} \\
\hline & & $\mathrm{Hr}$ & $S$ & $\mathrm{Hr}$ & $S$ & $\mathrm{Hr}$ & $S$ \\
\hline \multirow{2}{*}{ Plowing } & $0-15$ & 1,58 & 27,8 & 2,94 & 28,8 & 2,86 & 26,0 \\
\hline & $15-30$ & 1,42 & 26,4 & 2,26 & 27,2 & 2,66 & 28,4 \\
\hline \multirow{2}{*}{$\begin{array}{l}\text { Non-plow tillage on } \\
\text { different-depth }\end{array}$} & $0-15$ & 1,36 & 28,0 & 2,30 & 29,8 & 2,54 & 30,6 \\
\hline & $15-30$ & 0,94 & 26,0 & 1,72 & 28,6 & 1,88 & 28,8 \\
\hline \multirow{2}{*}{$\begin{array}{c}\text { Shallow } \\
\text { non-plow tillage }\end{array}$} & $0-15$ & 0,96 & 28,2 & 2,24 & 29,4 & 2,80 & 30,2 \\
\hline & $15-30$ & 0,44 & 26,0 & 1,40 & 27,44 & 2,04 & 27,8 \\
\hline
\end{tabular}

In typical chernozem, we can note similar patterns with podzolic chernozem in influence of tillage and fertilization systems on the indicators of physicochemical properties. Without the application of fertilizers, there is a tendency to reduce the hydrolytic acidity by increasing the degree of tillage minimization. The lowest values of the indicator were observed in the variant with systematic shallow non-plow tillage and generally in all variants the hydrolytic acidity did not reach critical values. Applying just straw and joint straw and green manure, it was observed the highest values of hydrolytic acidity during plowing $-2.66-2.86 \mathrm{mg}-\mathrm{eq} / 100 \mathrm{~g}$, although it did not exceed significantly the indicators of non-plow cultivation $(1.88-2.80 \mathrm{mg}-\mathrm{eq} / 100 \mathrm{~g})$. Differences in typical and podzolic chernozems in the influence of application straw and green manure on hydrolytic acidity can be explained by the peculiarities of the soils genesis, namely the last one tends to acidify the soil environment.

The application of organo-mineral fertilizer in the studied soil layers contributed to the increase of the amount of exchange bases on all cultivation options by $0.8-2.8 \mathrm{meq} / 100 \mathrm{~g}$ of soil. Different-depth non-plow tillage had an advantage in this indicator over plowing and shallow non-plow tillage, especially in the upper layer of the soil, where was the highest values of humus among the rates of fertilization. Thus, the minimization of tillage and biologization system of the fertilization makes possible to restore the fertility of typical chernozem.

\section{Conclusions}

It is established that the minimization of tillage and biologization of fertilizer systems, through the replacement of manure with straw and green manure restores the fertility of podzolic and typical chernozems. Prolonged application of organo-mineral fertilizer increases the content and reserves of humus in the upper half-meter layer of the soil, and tillage systems redistribute them depending on the nature and depth and the usage of fresh organic matter into the soil. The humus content of podzolic chernozem increases in the layer of $0-30 \mathrm{~cm}$ by $0.11-0.49 \%$ in comparison with the control, and reserves increase by $3.5-18.4$ t/ha, and typical chernozem increases accordingly by $0.46-0.65 \%$ and humus reserves by $9.0-16.1 \mathrm{t} / \mathrm{ha}$.

Tillage and fertilization systems changed the indicators of hydrolytic acidity and the amount of exchange bases of podzolic and typical chernozems and decreased by 0.82 and $2.6 \mathrm{mg}$-eq/100 $\mathrm{g}$ of soil with minimizing tillage. Using straw and green manure together with a high rate of mineral fertilizers on the background of plowing in podzolic chernozem, the hydrolytic acidity index increased to critical values (4.24 $4.38 \mathrm{mg}-\mathrm{eq} / 100 \mathrm{~g}$ of soil). The best indicators of the amount of exchange bases were observed in fertilized variants with non-plow tillage.

The best restoration of fertility of typical chernozem occurred with different depth non-plow tillage and usage of straw, green manure, mineral fertilizers, as for chernozem podzolic with non-plow tillage with periodic plowing and with application of manure or straw and green manure and full mineral fertilizer.

\section{References}

1. Mazur, H.A. (2012). Produktyvnist ahrotsenozu yak funktsiia rivnia vidtvorennia rodiuchosti gruntiv [Productivity of agrocenosis as a function of the level of soil fertility reproduction]. Bulletin of Agricultural Science, 12, 75-76. [in Ukrainian]. 
2. Kravchenko, Y.S., Chen, Q., Liu, X. et al. (2016). Conservation Practices and Management in Ukrainian Mollisols. J. of Agricultural Science and Technology (JAST), 18, 845-854.

3. Baliuk, S.A., Nosko, B.S., \& Skrylnyk, Ye.V. (2016). Suchasni problemy biolohichnoi dehradatsii chornozemiv i sposoby zberezhennia yikh rodiuchosti [Modern problems of biological degradation of chernozems and ways to preserve their fertility]. Bulletin of Agricultural Science, 1, 11-17. [in Ukrainian].

4. Yatsuka, I.P. (Ed.). (2015). Periodychna dopovid pro stan rodiuchosti gruntiv na zemliakh silskohospodarskoho pryznachennia Ukrainy: za rezultatamy 9 turu (2006-2010 roky) ahrokhimichnoho obstezhennia zemel [Periodic report on the state of soil fertility on agricultural lands of Ukraine: according to the results of the 9th round (2006-2010) of agrochemical survey of lands]. Kyiv: TOV «VYK-PRYNT». [in Ukrainian].

5. Demydenko, O.V. (2013). Retsyrkuliatsiine vidnovlennia fizyko-khimichnykh i ahrofizychnykh vlastyvostei u protsesi gruntoutvorennia chornozemu typovoho livoberezhnoho lisostepu [Recirculation restoration of physicochemical and agrophysical properties in the process of soil formation of chernozem of a typical left-bank forest-steppe]. Collection of scientific works of NSC "Institute of Agriculture of NAAS", 1-2, 26-37. [in Ukrainian].

6. Tsiuk, O.A. (2015). Zminy pozhyvnoho rezhymu v ahrofitotsenozi pshenytsi ozymoi zalezhno vid system osnovnoho obrobitku [Changes in the nutritional regime in the agrophytocenosis of winter wheat depending on the systems of main cultivation]. Scientific Bulletin of NULES of Ukraine, 210(1), 156-161. [in Ukrainian].

7. Dotsenko, O.V. (2012). Humusnyi stan chornozemu typovoho pid vplyvom tryvaloho vnesennia dobryv [Humus condition of typical chernozem under the influence of long-term fertilization]. Bulletin of Agricultural Science, 12, 75-76. [in Ukrainian].

8. Ukraine: Soil fertility to strengthen climate resilience Preliminary assessment of the potential benefits of conservation agriculture, FAO. World Bank [Ukraine: Soil fertility to strengthen climate resilience Preliminary assessment of the potential benefits of conservation agriculture, FAO. World Bank]. FAO UN Rome, 2014.

9. Pikovska, O.V., \& Vitvitska, O.I. (2016). Vplyv zastosuvannia solomy na pokaznyky rodiuchosti chornozemu typovoho [Influence of straw application on typical chernozem fertility indicators]. Scientific Bulletin of NULES. Agronomy series, 235, 160-166. [in Ukrainian].

10. Volkohon, V., Pyrig, O., Volkohon, K., \& Dimova, S. (2019). Methodological aspects of determining the processes of organic matter mineralization $\leftrightarrow$ synthesis in croplands. Agricultural Science and Practice, 6(1), 3-9.

11. Balaiev, A.D., Havryliuk, M.V., \& Stopa, V.P. (2013). Rodiuchist chornozemiv Lisostepu za vykorystannia minimizatsii obrobitku gruntu i elementiv biolohizatsii zemlerobstva [Fertility of chernozems of the Forest-Steppe with the use of minimization of tillage and elements of biologization of agriculture]. Bulletin of Kharkiv National Agrarian University. Series: Soil Science, Agrochemistry, Agriculture, Forestry, 1, 8-11. [in Ukrainian].

12. Bobos, I., Fedosy, I., Zavadska, O. et al. (2019). Optimization of plant densities of dolichos (Dolichos lablab I. var. lignosus) bean in the right-bank of forest-steppe of Ukraine. Agronomy Research, 17(6), 2195-2202.

13. Balaiev, A.D., \& Tonkha, O.L. (2013). Gruntozakhysna biolohichna systema zemlerobstva i vidtvorennia rodiuchosti gruntiv [Soil-protective biological system of agriculture and reproduction of soil fertility]. Bulletin of the National University of Water Management and Environmental Sciences, 3(63), 3-14. [in Ukrainian].

14. levtushenko, T.V., \& Tonkha, O.L. (2017). Umist i zapasy humusu zalezhno vid udobrennia i obrobitku chornozemu typovoho [Content and reserves of humus depending on the fertilizer and cultivation of typical chernozem]. Scientific Bulletin of NULES of Ukraine. Agronomy series, 269, 168-176. [in Ukrainian].

15. DSTU 4287: 2004. Soil quality. Sampling. [Effective from 2005-07-01]. Kyiv: Derzhspozhyvstandart Ukrainy, 2005. [in Ukrainian].

16. DSTU 4289: 2004. Soil quality. Methods for determination of organic matter. [Valid from 2004-04-30]. Kyiv: Derzhspozhyvstandart Ukrainy, 2005. (National standards of Ukraine). [in Ukrainian].

17. GOST 27821-88. Soils. Determination of the sum of absorbed bases by the Kappen method (Soils. Determination of the sum of absorbed bases by the Kappen method). [in Russian].

18. GOST 26212-91. Soils. Determination of hydrolytic acidity by the method of Kappen in the modification of CINAO (Soils. Determination of hydrolytic acidity by the method of Kappen in the modification of CINAO). [in Russian].

19. Tonkha, O.L., Sychevskyi, S.O., Pikovskaya, O.V., \& Kovalenko, V.P. (2018). Modern approach in farming based on estimation of soil properties variability. Paper presented at the 12th International Scientific Conference \&amp; Quot; Monitoring of Geological Processes and Ecological Condition of the Environment\&amp; Quot.

20. Rusu, Teodor, loan, Pacurar, Marcel, Dîrja et al. (2013). Effect of tillage systems on soil properties, humus and water conservation. Agricultural Sciences, 4, 35-40. 
21. Balaiev, A.D., Pavliuk, S.D., \& Yevpak, I.V. (2009). Fizyko-khimichni vlastyvosti chonozemu typovoho za zastosuvannia minimizatsii obrobitku gruntu i biolohizatsii zemlerobstva [Physico-chemical properties of chonozem typical for the application of minimization of tillage and biologization of agriculture]. Scientific Bulletin of the National University of Life and Environmental Sciences of Ukraine, 134(3), 124-131. [in Ukrainian]. 